\title{
BACKHOME: Transformation of Old Shop Houses into a Contemporary Backpackers' Hostel with Better Indoor Environmental Quality
}

\author{
Nik Lukman Nik Ibrahim \\ Department of Architecture and Built Environment, Faculty of Engineering and Built Environment, The National University of \\ Malaysia (Universiti Kebangsaan Malaysia - UKM), Bangi, 43600, Selangor, Malaysia
}

Received July 8, 2021; Revised September 29, 2021; Accepted October 21, 2021

Cite This Paper in the following Citation Styles

(a): [1] Nik Lukman Nik Ibrahim, "BACKHOME: Transformation of Old Shop Houses into a Contemporary Backpackers' Hostel with Better Indoor Environmental Quality," Civil Engineering and Architecture, Vol. 9, No. 7, pp. 2169-2177, 2021. DOI: 10.13189/cea.2021.090706.

(b): Nik Lukman Nik Ibrahim (2021). BACKHOME: Transformation of Old Shop Houses into a Contemporary Backpackers' Hostel with Better Indoor Environmental Quality. Civil Engineering and Architecture, 9(7), 2169-2177. DOI: 10.13189/cea.2021.090706.

Copyright $(2021$ by authors, all rights reserved. Authors agree that this article remains permanently open access under the terms of the Creative Commons Attribution License 4.0 International License

\begin{abstract}
BACKHOME is a backpacker hostel in Kuala Lumpur city centre designed by Ar. Masyerin Md Nor, the principle of Domaine Architects Sdn Bhd. The design of this backpacker hostel had won the prestigious PAM Award in 2016 for commercial building. The travellers' sanctuary was originally four units of shop houses built in the 1970's. It was remodelled into a stylish and contemporary hostel to accommodate tourists visiting Kuala Lumpur or transiting to neighbouring countries such as Thailand, Indonesia and Singapore. Set amidst the hustle and bustle of Kuala Lumpur city centre, this hostel is a peaceful sanctuary for travelling backpackers. The refurbishment of the shop houses has provided better indoor environmental quality achieved through design strategies for natural ventilation and daylighting. This article reviews BACKHOME based on the current trend of adaptive reuse criteria usually adopted locally and also internationally. These include sustainability, construction, public engagement and historical aspects. From the review, it shows that the novelty of the scheme adopted in BACKHOME lies in the innovative engagement of these criteria. The scheme realised and manifested in BACKHOME can be very impactful in paving a new mode of adaptive reuse practice in Malaysia. This article highlights the essential aspects of the success of BACKHOME which could be emulated in any future adaptive reuse project especially involving heritage shop
\end{abstract}

houses in this country.

Keywords Adaptive Reuse, Backpacker Hostel, Heritage Building, Indoor Environmental Quality

\section{Introduction}

BACKHOME is an adaptive reuse architecture project which falls into the category of sustainable development. It conforms to what Tam and Hao [1] describe as a process of developing structurally-sound-old-building into an economically viable architecture which also reduces consumption during reconstruction and represents a new way of thinking and responding to climatic context. The architectural work involves refurbishment of existing building to serve contemporary usage while preserving and reusing features from the past. In general, the building complex consists of a backpacker hostel called BACKHOME and a coffee house for LOKL Coffee company (Figure 1). Located in Jalan Tun HS Lee (Figure 2), the hostel is within a walking distance to Central Market, Petaling Street Market and other Kuala Lumpur central city attactions. It was designed to accomodate 60 backpackers or visitors in six dormitories of different sizes or floor areas. 


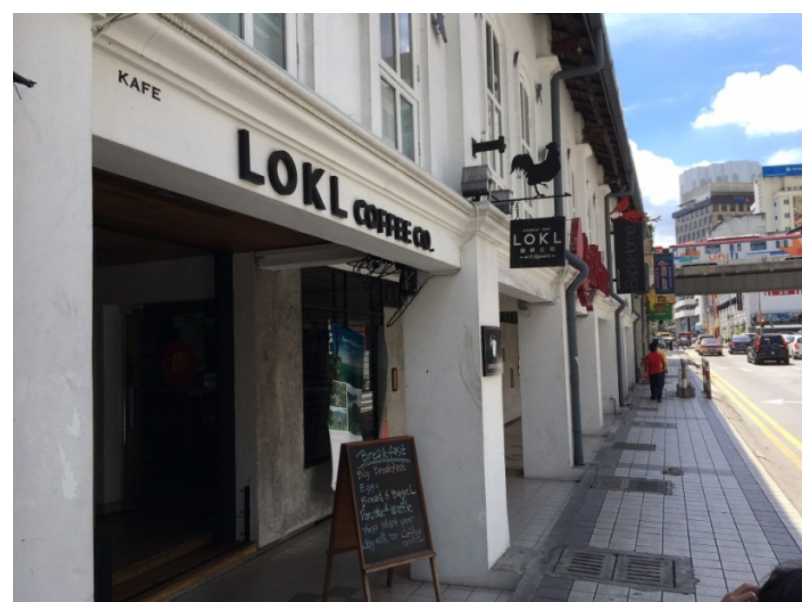

Source: photo by the Author
The client requested for a building which has the ambience of Melaca style Kopitiam place thus appropriating and capitalizing on the unique architecture of the original heritage shop houses. The original structure consisted of four abandoned units of shop houses built in the 1970's (Figure 3). The shop houses were constructed on the site of earlier shop houses built before world war II which were bombed and destroyed during the war. The transformation of these abondoned shop houses into a backpackers' hostel called BACKHOME actually improves the indoor environmental qualities of the building complex in terms of natural ventilation and daylighting. The refurbishment opens up the dense building complex into loose volumes of indoor and semi-outdoor spaces.

Figure 1. The current façade of BACKHOME

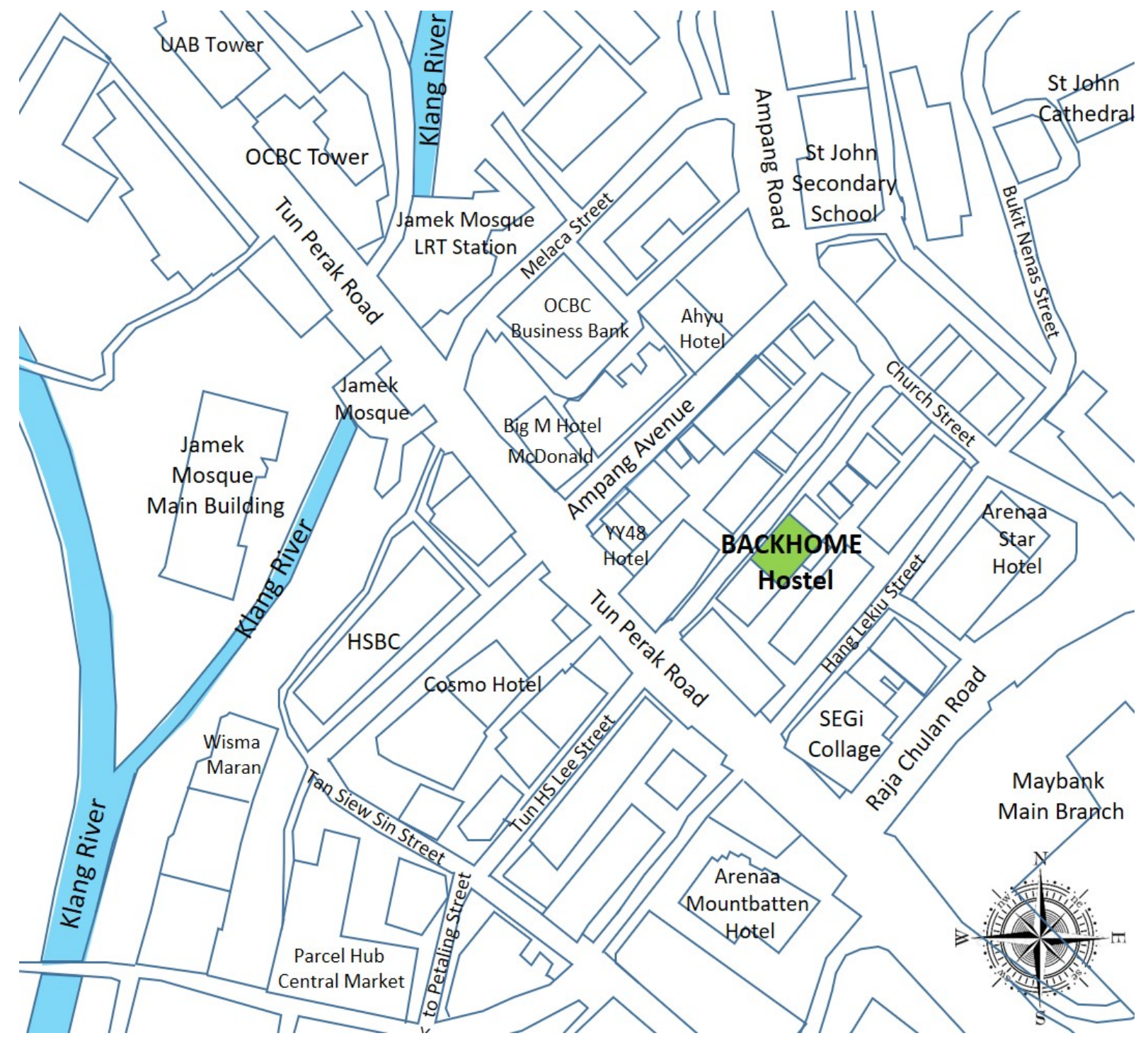

Source: illustration by the Author on the basis of www.google.com/maps/place/Back+Home+Kuala+Lumpur+Hostel/

Figure 2. The location plan of BACKHOME 

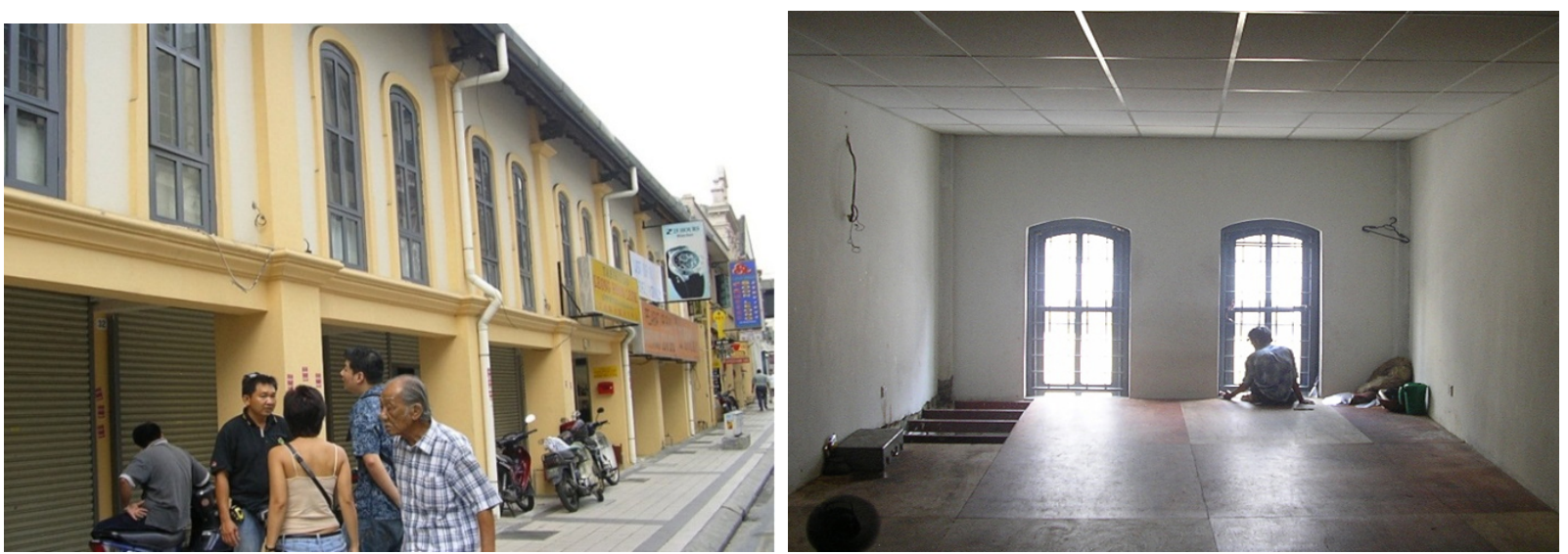

Source: photos by M. Md. Nor

Figure 3. Previous shop houses façade and interior space

This innovative design intervention at BACKHOME is parellel to what Sulimowska-Ociepka [2] conceptualises about cultural heritage which encompasses the creative use of historical buildings for contemporary purposes and not merely about protecting or preserving the old fabrics and activities. A city can enrich it's image and cultural landscape by this evolution of historical construction which can also be more socially engaging.

\section{Adaptive Reuse of the Heritage Shop Houses}

Abdullah et al. [3] have summarised six main criteria for the implementation of adaptive reuse on the redevelopment of heritage shop houses in Malaysia. These criteria are economic, environment, social, architecture, technology and legislative. In brief, adaptive reuse of heritage shop houses should satisfy potential market, encourage positive environmental effect, retain a sense of place for the comunity, preserve existing architecture features, maintain good structural condition and adhere to the local zoning regulation and building code of practice. All these criteria have been met in the design, construction and operation of BACKHOME with special distinctions achieved in the environmental, social and technological aspects.

\subsection{Design Scheme for Better Indoor Environmental Quality}

The adaptive reuse of heritage shop houses in Malaysia has to conform to the requirements of the National Heritage Act 2005 formerly known as the Antiquity Act
1976 [4]. A large number of adaptive reuse projects on shop houses can be found in the heritage city of Georgetown, Penang. Most of these shop houses have been beautifully reconstructed to highlight the rustic character and ambience of this heritage town protected under UNESCO. However, not many of these shop houses are parellel to BACKHOME in terms of design originality and innovation in construction.

In the design scheme, Domaine Architects Sdn Bhd proposed the back of the shop houses to be demolished to provide an elongated open space or courtyard and a new block connected by an elevated bridge or an 'open air corridor'. The inclusion of the courtyard space has opened up the row of compact shop houses quite significantly (Figure 4). The previous tightly linked and enclosed buildings have been ingeniously reconfigured to give way to a semi outdoor internal court area. This new configuration has ample courtyard space which is opened to the sky and allows better air movement, ventilation and natural daylight for the building's indoor spaces. BACKHOME's courtyard is enclosed by the old and new walls creating an inward-looking micro urban space. The envelopes protect the courtyard from direct sunlight penetration and transfer of tropical heat, an environmental strategy described by Ivan S. et al. [5] as characteristic to a bioclimatic design. As a result the new design layout has much better indoor environmental quality compared to the previous building layout before the renovation. Similar environmental benefits from adaptive reuse of old buildings have been promoted by Kirovová and Sigmundová [6]. These researchers suggest that proper adaptive reuse should improve the site's ecosystem and the surrounding urban environment. 

with Better Indoor Environmental Quality

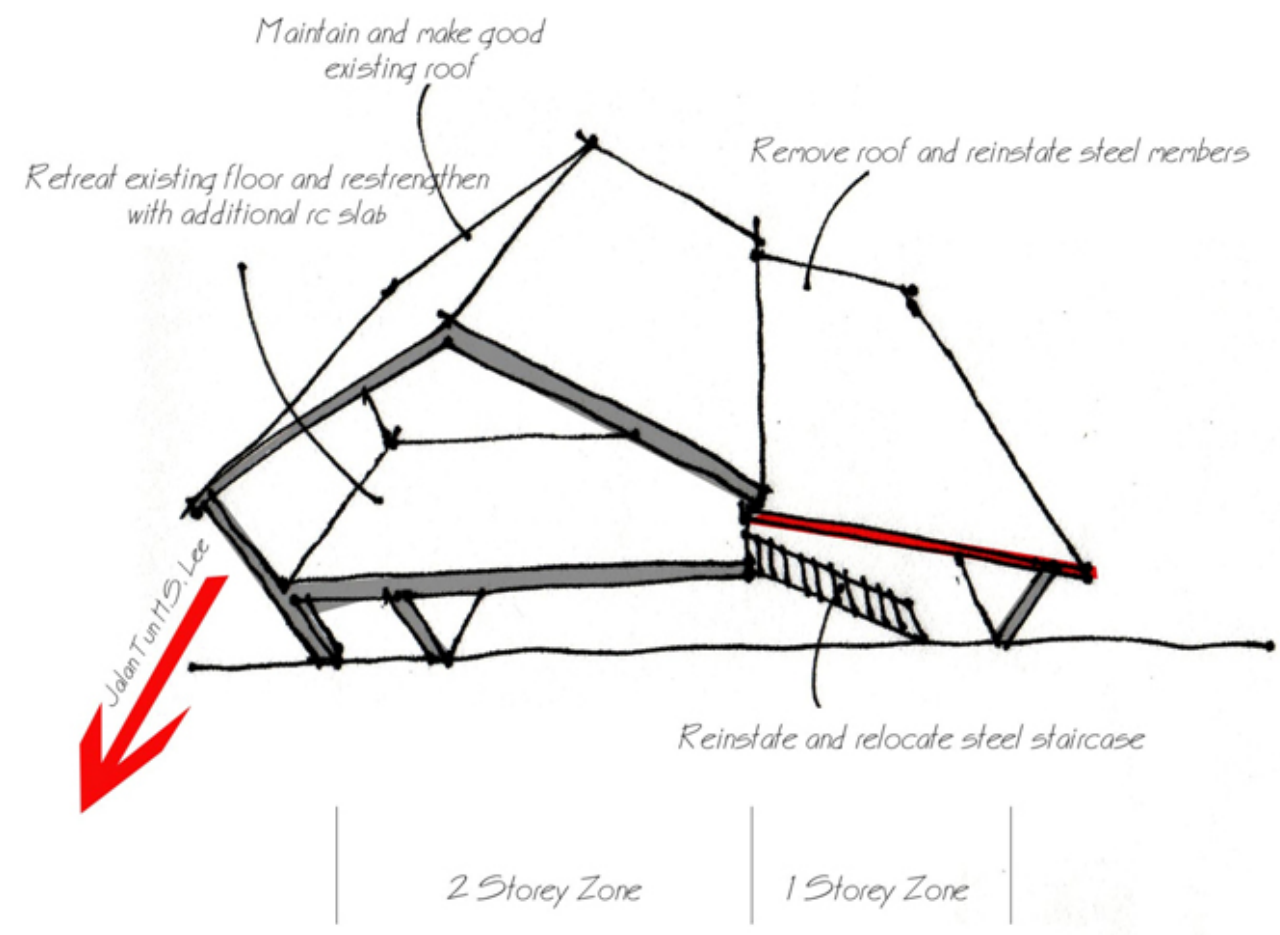

BEFORE

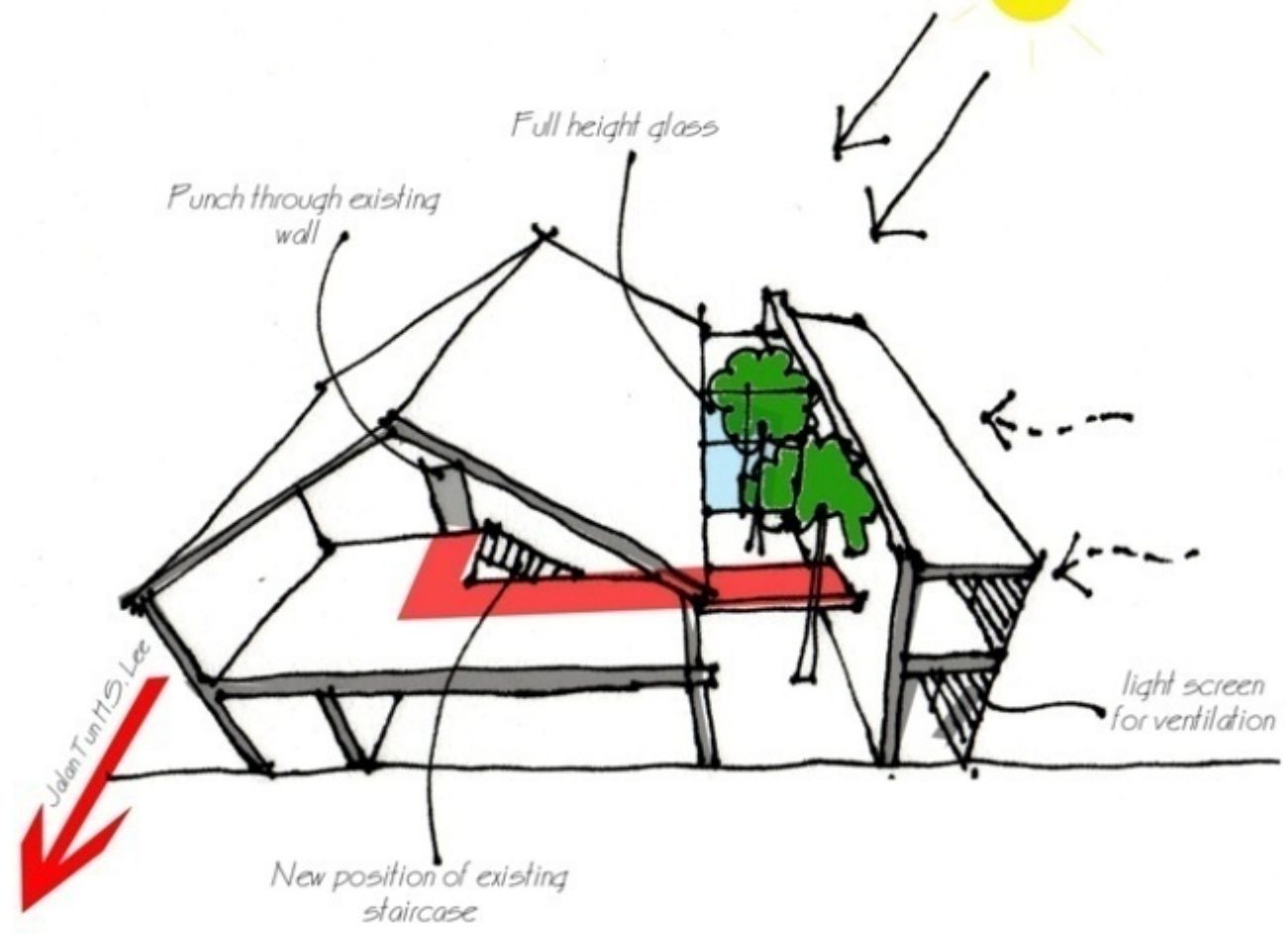

ZONEI \begin{tabular}{l|l} 
ZONE2 & ZONE3
\end{tabular}

AFTER

Source: illustrations by M. Md. Nor

Figure 4. Design strategy for daylighting and natural ventilation 

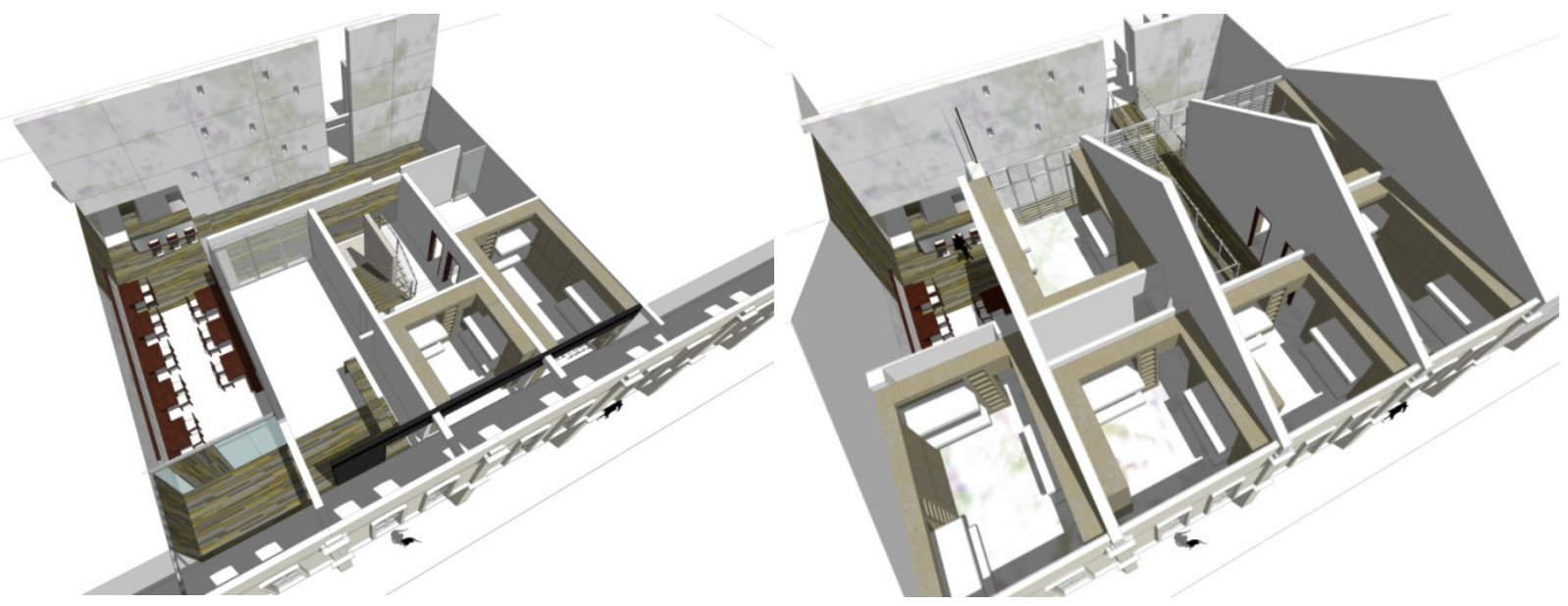

Source: illustrations by M. Md. Nor

Figure 5. Axonometric views of the ground floor and the $1^{\text {st }}$ floor

In the current scheme, a new bare concrete wall was erected to accentuate the new block which creates a strong presence and feature in the couryard space. The cafe intrudes and blends into the courtyard space, inviting people to enjoy the semi opened internal space with fresh air and free from the noise of the city traffic. Above the courtyard, a steel sky bridge with timber flooring provides a link between the dormitories in the old block and the washrooms of the new block (Figure 4 and Figure 5). Not all adaptive reuse of shop houses in Kuala Lumpur addressed sustainability issue as reported by Al-Obaidi et al. [7] and some have faced deteriorating indoor environmental quality such as inadequate natural ventilation and poor daylighting. These two criteria of indoor environmental quality have been satisfactorily met in the design of BACKHOME.

\subsection{Construction Method and Materials}

The low plywood ceilings of the old buildings were stripped to expose the high roof rafters above. This provides the interior space with higher roof space or volume which also improves indoor air circulation. The timber floor of the first storey were dismantled and replaced by concrete floor. The new construction utilized steel roof rafters and concrete floor for better durability. The original timber ceilings and the wooden floor planks were not disposed off totally but reused in the new construction elements and process. One of the original steel staircases of the shop houses was maintained and reused in the new scheme. These new adaptations of old elements into new configurations with well-thought intervention of new elements actually improve the indoor environment quality. Recyclying of the old fabrics and enhancing the environmental aspects are the key sustainable features in BACKHOME's design.

The concrete wall of the new block was constructed using precast concrete panels (Figure 6). The construction of this concrete wall is one of the unique technique applied in this adaptive reuse project. The old plywood sheets dismantled from the original shop houses were turned into moulds for the precast concrete panels. BRC wire meshes were placed inside the moulds and concrete was poured to form the concrete panels. The precast concrete panels were actually manufactured or casted on site using the recycled plywood sheets and timber panels from the old shop houses as moulds. This construction method actually dispensed with the moulds fabrication and transportation costs of delivering precast concrete panels to the site. The project demonstrated a recommendable recycling practice by reusing demolished materials as elements in the new project as well as means of fabricating new construction elements.

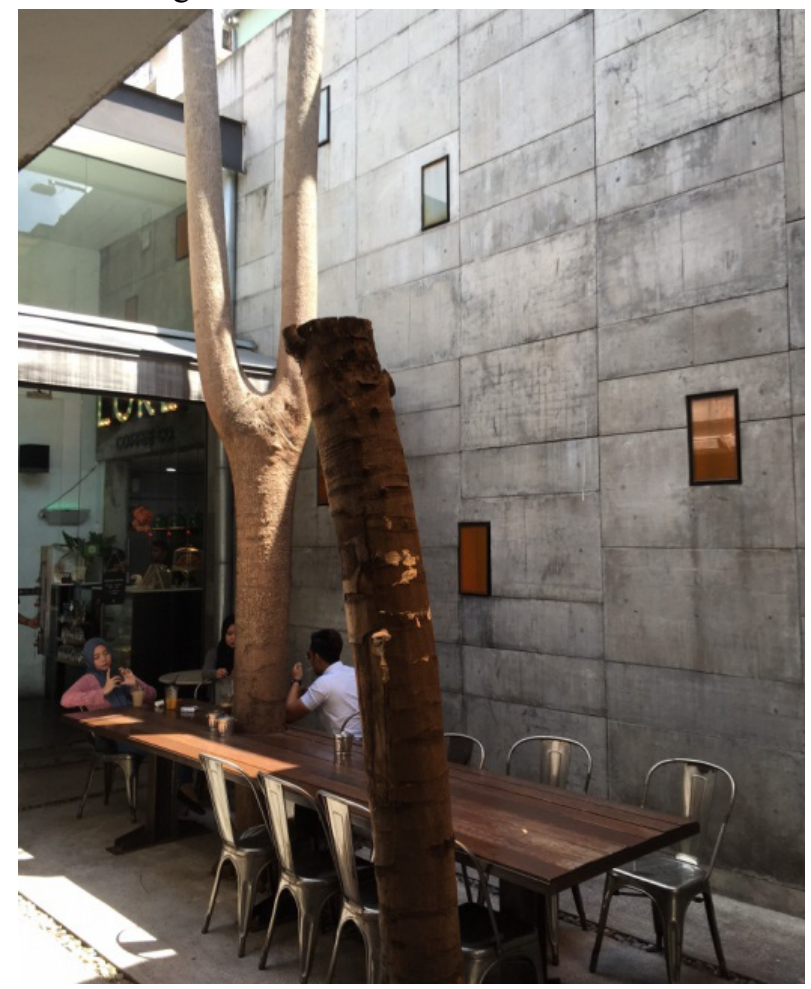

Source: photo by the Author

Figure 6. Courtyard spaces showing the new concrete wall of precast panels 


\subsection{Social Green Space}

Other than providing better indoor environmental quality for the hostel, the courtyard allows smooth transition from public to semi-private space and acts as an extension of the living space for the hostel dwellers. The dinning area as indicated in the first floor plan (Figure 7) is actually occupied by the LOKL cafe. From the building's five foot way, visitors will enter a small foyer leading to LOKL cafe or BACKHOME hostel reception through two separate doors.
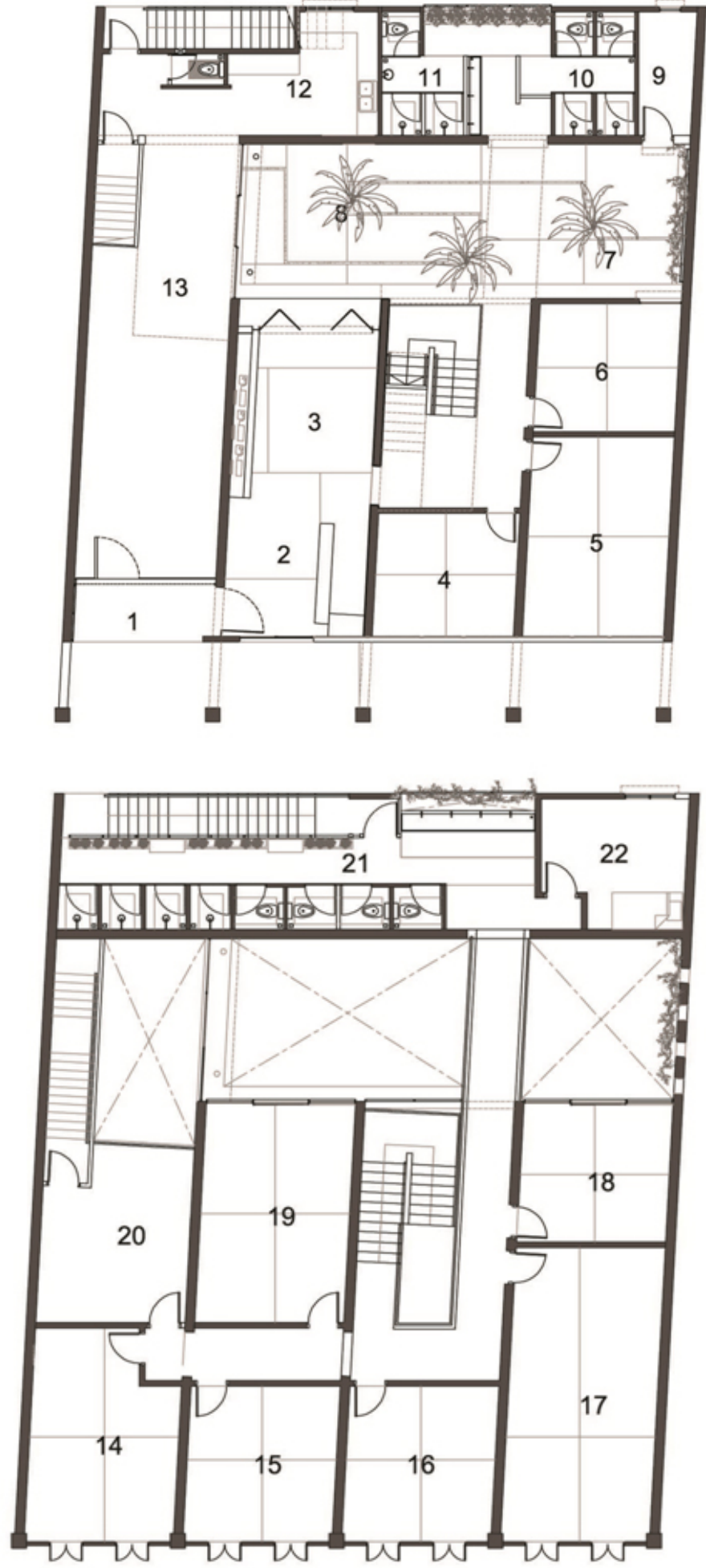

Source: illustrations by M. Md. Nor

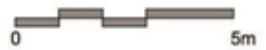

1. Entrance Foyer

2. Reception

3. Guest Lounge

4. 4 Pax Dormitory

5. 6 Pax Dormitory

6. Premium Twin Room

7. Guest Courtyard

8. Diner Courtyard

9. Laundry Room

10. Female Washroom

11. Male Washroom

12. Kitchen

13. Dining area
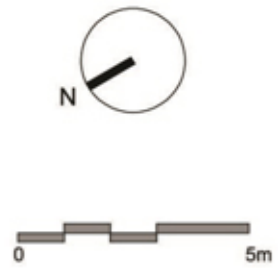

14. 6 Pax Dormitory

15. 4 Pax Dormitory

16. 4 Pax Dormitory

17. 8 Pax Dormitory

18. Premium Twin Room

19. 6 pax Dormotory

20. Lounge

21. Communal Washroom

22. Caretaker's Room

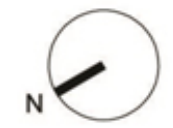

Figure 7. Ground and first floor plans of BACKHOME 


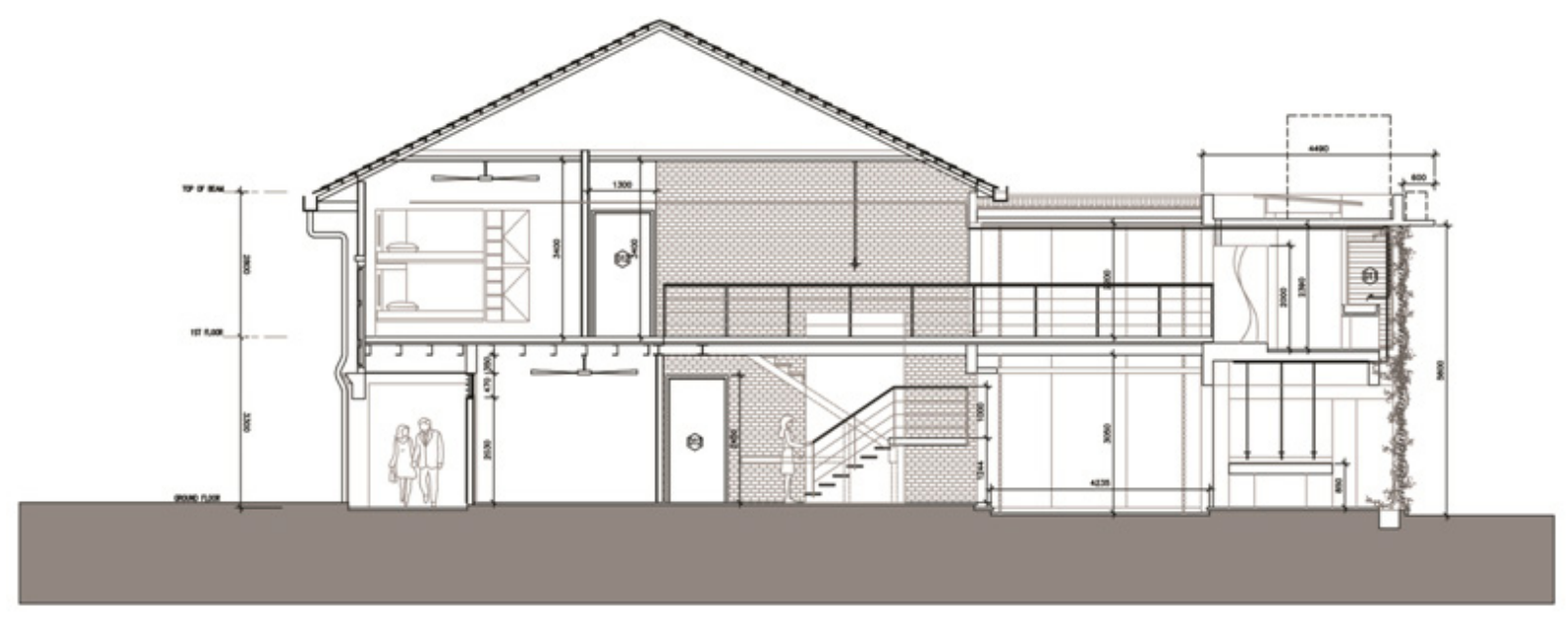

Source: illustration by M. Md. Nor

Figure 8. Cross section through the courtyard, lounge, a dormitory and washrooms

The lounge beside the reception counter overlooks the courtyard and serves as a waiting area equipped with computer and internet facilities. A hostel's guest can actually sit on the enlarged window sill of the lounge facing the courtyard while enjoying a book or a cup of tea or coffee.

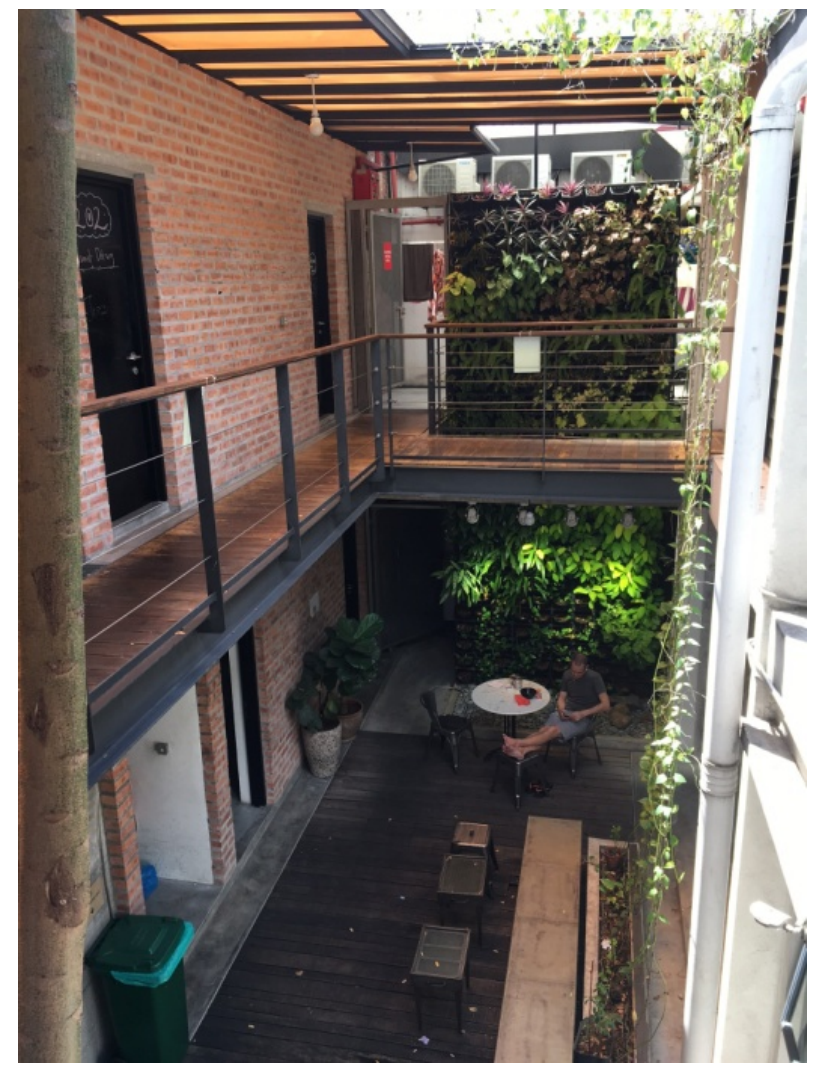

Source: photo by the Author

Figure 9. The green wall of vertical landscape stretching up two storey height

The serene ambience of the courtyard is further reinforced by the presence of a few tall trees providing shades and a green wall planted with climbers at the other end of the open space. The presence of trees helps to reduce carbon dioxide particles in the air through photosynthesis and release oxygen to the surround. The two floor height green landscape wall acts as a feature wall which counter-balances and softens the monotony and roughness of the extensive bare precast concrete wall (Figure 8 and Figure 9). This open and green social space serves as a biophilic element in the hostel design which is very essential as the building is located in a congested area in the middle of Kuala Lumpur.

\subsection{Merits of Adaptive Reuse}

BACKHOME is a backpackers' hostel which assumes the ambience of the historical Melaca style Kopitiam place through the synthesis of the old and new elements. Malaca Kopitiam is the traditional shop house cafe in the historical city of Malaca which serves coffee and meals on the ground level and accomodates a dwelling unit on the upper floor. The adaptive reuse building could also be categorised as a heritage tourism design scheme. It focuses on the public visitation behaviour based on architectural motivation and appreciation as described by Ariffin et al. [8]. The building design, fabric and ambience can influence people's appreciation toward historical building based on it's background, uniqueness and familiarity. According to Suet Kay [9] rejuvenation of pre-war buildings as tourist attractions has also been a growing trend in Kuala Lumpur city centre since the past several years.

BACKHOME also fullfill the four main criteria for adaptive reuse as summarized by Wilkinson and Reed [10] which consist of social, environmental, economic and technological factors. BACKHOME is praiseworthy socially in preserving the old buildings for future generations, revitalising the neighbouhood and controling urban sprawl of gigantic tall commercial buildings in Kuala Lumpur. Environmentally it is sustainable, using 
less construction materials and saving energy through strategies of natural ventilation, air cooling and daylighting. BACKHOME also makes sense in terms of the economy or construction coast by being cheaper than if it was to be totally demolished and rebuilt. Technologically, the integration of the new precast concrete construction with the old fabric was well executed and innovative. At the same time, recycling of the demolished building materials became part of the construction process. Hanafi et al. [11] highlight that criteria usually affecting decision for adaptive reuse in Malaysia include the building's physical condition, functional aspect, finance, law and regulation, infrastructure and politics. They also highlight that social, environment and economic criteria are the three main factors in determining adaptive reuse decison in Malaysia as proven statistically in their survey. Undoubtably, these three criteria have been the underlying factors behind the realization of BACKHOME.

\subsection{Future Outlook of Heritage Shop Houses Adaptive Reuse}

The success of BACKHOME should encourage similar future adaptive reuse projects in Kuala Lumpur or other historic sites in Malaysia. Zainudin et al. [12] claim that the building information modelling (BIM) used in the current local architecture practice can help simulate environmental performance and costs of historical building to undergo adaptive reuse. Although awareness and adoption of architecture digital innovation had been minimal in Malaysia over the past several years [13], the current growing trend of BIM usage in the local architecture practice could potentially aid and stimulate adaptive reuse of heritage buildings in the future.

As posited by Clark [14] adaptive reuse can actually link a building to the past, the present and the future. It can give new life to a site and building rather than freezing it or demolishing the existing fabric and context. It can add a new layer without erasing the earlier constructed layer and the new scheme will become part of the extended history of the building and the site. Selected heritage fabrics can be maintained and amplified for new roles and for later generations to appreciate them. Adaptive reuse of heritage buildings has been linked to sustainable urban development and low carbon cities of the future [15]. This future prospect has promoted revitalisation of many heritage buildings of cultural and historical significance to be adapted and reused rather than subjected to demolition in many developed countries [16].

The benefits of urban sustainability and heritage preservation have been realised superlatively in the adaptive reuse execution of BACKHOME. Similar adaptive reuse projects to BACKHOME can hinder undesirable urban sprawl and senseless demolition of old buildings that had been widespread over the past few decades in Malaysia. Future project of shop houses adaptive reuse in Malaysia can take BACKHOME as an example or precedent.

\section{Conclusions}

BACKHOME has the advantage of being in the central location of Kuala Lumpur whilst assuming an ambience of a sanctuary and enjoying better indoor environmental quality compared to a similar average accomodation in the city centre. The remodelling or adaptive reuse of the historical shop houses was well executed by Domaine Architects who have turned the old buildings into a peacefully retreat or santuary for travellers, free from the hustle and bustle of the city centre. The design has largely preserved the architecture of the heritage shop houses while inserting new programs and activities which enliven the building beyond its original scheme. The green communal space inside BACKHOME is a unique and humane intervention in the midst of Kuala Lumpur urban area which is congested with buildings mostly deprieved of this essential quality. It has opened up a compact configuration of buildings into a serene ambience with better indoor environmental quality. BACKHOME has made a contribution to sustainable development in Kuala Lumpur through retrofiting of old shop houses which by normal practice were usually demolished to give way to new featureless commercial buildings. The executed design scheme is socially, economically and environmentally sound with a promise to a better future. The significant features of BACKHOME include creative reuse of old fabrics, creation of new indoor and semi-outdoor spaces for social interaction and better internal environment ambience or qualities. Most importantly, the design scheme has preserved the historical fabrics and features of the city for later generations to appraise and remember. It has added a new layer of construction and programs to the old building complex for it to remain relevent in the current context and situation. The adaptive reuse design scheme of BACKHOME can be regarded as a part of the larger cultural production and enhancement for the city of Kuala Lumpur.

\section{Acknowledgments}

The author would like to express gratitude to the Universiti Kebangsaan Malaysia (UKM) for the allocated research grant GUP-2018-095 on habitable building's indoor environmental quality which had prompted this article. 


\section{REFERENCES}

[1] V.W.Y. Tam, and J.L. Hao. Adaptive Reuse in Sustainable Development, International Journal of Construction Management, Vol.19, Iss.6, 507-521, 2019.

[2] A. Sulimowska-Ociepka. Glass Structures in Post-Industrial Buildings and the Role of the Industrial Heritage in Shaping Creative Urban Spaces, Civil Engineering and Architecture, Vol.9, No.2, 281-292, 2021. DOI: 10.13189/cea.2021.09020 2.

[3] Abdullah et al. Criteria for Adaptive Reuse of Heritage Shop Houses Towards Sustainable Urban Development, International Journal of Sustainable Construction Engineering and Technology, Vol.11, No.1, 42-52, 2020.

[4] M.A.O. Mydin, N.A. Keling,, N. Md. Sani and N.F. Abas. Assessment of Adaptive Reuse of Heritage Shop Houses for Sleeping Lodging in Malaysia: Fulfillment of conservation guidelines, SHS Web of Conferences, EDP Sciences. 2014.

[5] Ivan S. et al. Heat Transfer Model of a Structural Element for the Transformation of Housing Sustainability, Civil Engineering and Architecture, Vol.8, No.4, 450-455, 2020. DOI: $10.13189 /$ cea.2020.080407.

[6] L. Kirovová and A. Sigmundová. Implementing an Ecosystem Approach to Adaptive Reuse of Industrial Sites, Ecology on The Built Environment, Vol.142, WIT Press, 433-444, 2014.

[7] Al-Obaidi et al. Sustainable Building Assessment of Colonial Shophouses after Adaptive Reuse in Kuala Lumpur, Buildings, 7 (4), 87, MDPI, 2017.

[8] Ariffin et al. Adaptive Reuse of Historical Buildings and Local Residents' Actual Visitation, Journal of Tourism, Hospitality and Culinary Arts, Vol. 9(2), 35-46, 2017.

[9] R.C. Suet Kay. In with the Old: Comunity Participation in
Heritage Management in Selected Malaysian Tourist Sites, JATI-Journal of Southeast Asian Studies, Vol.24(2), 131-154, Dec. 2019.

[10] Wilkinson and Reed. The Business Case for Incorporating Sustainability in Office Buildings: the Adaptive Reuse of Existing Buildings, Proceedings of the 14th Annual Conference of the Pacific Rim Real Estate Society (PRRES): Investing in Sustainable Real Estate Environment, 2008.

[11] Hanafi et al. Essential Entities Towards Developing an Adaptive Reuse Model for Organization Management in Conservation of Heritage Buildings in Malaysia, Environmental-Behaviour Proceedings Journal (6th AMER International Conference on Quality of Life), e-International Publishing House Ltd., Mar. 2018.

[12] Zainudin et al. Utilization of Building Information Modeling (BIM) in Planning an Adaptive Reuse Project of a Traditional Malay House (TMH), in 22nd International Conference on Virtual System \& Multimedia (VSMM), Oct. 2016.

[13] R. Ramilo and M.R. Embi. Digital Innovation in Architecture: Key Determinants and Barriers in the Case of Small Architectural Firms, The 7th International Conference of the Arab Society for Computer Aided Architectural Design (ASCAAD), April 2014.

[14] J. Clark. Adaptive Reuse of Industrial Heritage: Opportunities and Challenges, Heritage Council Victoria, 2013.

[15] E.H.K. Yung and E.R.W. Chan. Implementation Challenges to the Adaptive Reuse of Heritage Buildings: Towards the Goals of Sustainable, Low Carbon Cities, Habitat International, Vol.36, Issue.2, 352-361, 2012.

[16] P.A. Bullen and P.E.D. Love. The Rhetoric of Adaptive Reuse or Reality of Demolition: Views from the Field, Cities, Vol.27, No.4, 215-224, 2010. 